\title{
Auriferous sulfides from Hired gold mineralization, South Birjand, Lut block, Iran
}

\author{
Hassan EshrAGHI ${ }^{*}$, Ebrahim RASTAD ${ }^{* *}$ and Kamran Motevali* ${ }^{* *}$ \\ *Pars Oil \& Gas Company, NO 133, parvin Etesami St. Fatemi, Tehran, Iran \\ *** Department of Geology, School of Basic Science, \\ University of Tarbiat Modares, Tehran, Iran
}

\begin{abstract}
The Hired gold mineralization is located in the Lut Block, eastern Iran. Reduced intrusion of subvolcanic granodiorite to quartz diorite stock with porphyry texture of the post Eocene age intruded into the Eocene volcanics and pyroclastic units led to alteration and gold mineralization. Mineralization occurred as three separate parts: intrusion-hosted, proximal and distal. The Hired gold mineralization can be considered as gold mineralization related to reduced granitoid intrusions. Free gold has not been observed in the form of native gold during microscopic studies. Therefore, it appears that gold probably occurs as invisible or submicrometer-sized inclusions in sulfide minerals. Electron probe microanalysis (EPMA) confirmed the existence of sulfide minerals such as pyrrhotite, galena, pyrite and arsenopyrite having the highest gold content; however, because of the relative abundance of pyrite and arsenopyrite, a high gold concentration corresponds to the presence of these sulfides. Considering the paragenetic sequences, gold mineralization occurred as invisible gold in the early and late hydrothermal stages.
\end{abstract}

Keywords: Gold mineralization, Invisible gold, Hired, Iran

\section{INTRODUCTION}

The Hired gold mineralization is located $140 \mathrm{~km}$ south of Birjand in the Lut Block, Eastern Iran. Most of the Lut Block is covered with volcanic rocks related to the closure of the Neo-Tethys, locally known as the Sistan Ocean (Sengor, 1990), between the Helmand and Lut plates that caused Cenozoic magmatism in the Lut Block. This magmatism includes basalt, dacite, andesite, rhyolite and ignimbrite that mainly exhibit calc-alkalic affinities. Granitoid bodies of the Upper Jurassic and Tertiary age outcrop in this block (Camp and Griffis, 1982; Tirrul et al., 1983).

In recent decades, the Lut Block has been a focus of gold prospecting. Geochemical explorations, economic geology, remote sensing and geophysics studies in eastern Iran, led to the recognition of various promising mineralized areas. These areas include Hired (related to reduced intrusion), Maherabad (Cu-Au porphyry), Shurab (intermediate-sulfidation epithermal) and Khonick (intrusionrelated breccia pipe) (Sillitoe, 2005). The presence of mineralization in the Lut block may indicate that Tertiary

doi:10.2465/jmps.070414b

H. Eshraghi, HEshraghi@pogc.ir Corresponding author volcano-plutonic units in this area have great potential for gold mineralization (Eshraghi, 2006). The main objective of the present study is the recognition of $\mathrm{Au}$-bearing sulfides in the Hired gold mineralization

\section{GEOLOGICAL SETTING AND MINERALIZATION}

The old outcropped lithlogical units of the Jurassic and Cretaceous age in the Hired area are covered by Tertiary volcano-sedimentary sequences. Granite, granodioritequartz diorite, and gabbronorite plutons intruded into the Tertiary sequences (Fig. 1); however, mineralization occurred within or peripheral to the subvolcanic granodiorite-quartz diorite stock with porphyry texture. Due to the existence of ilmenite within the subvolcanic granodioritequartz diorite bodies and the lack of magnetite, low magnetic susceptibility $\left(1.5 \times 10^{-4} \mathrm{SI}\right.$ Units $)$, and low $\mathrm{Fe}_{2} \mathrm{O}_{3} /$ $\mathrm{FeO}$ ratio $(<0.5)$, they can be classified as ilmenite or reduced (low $f_{\mathrm{O}_{2}}$ ) granitoids (based on Ishihara's classification, 1981).

Based on the distance from the intrusion, the Hired gold mineralization occurred as three separate parts: intrusion-hosted, proximal, and distal. These three zones 


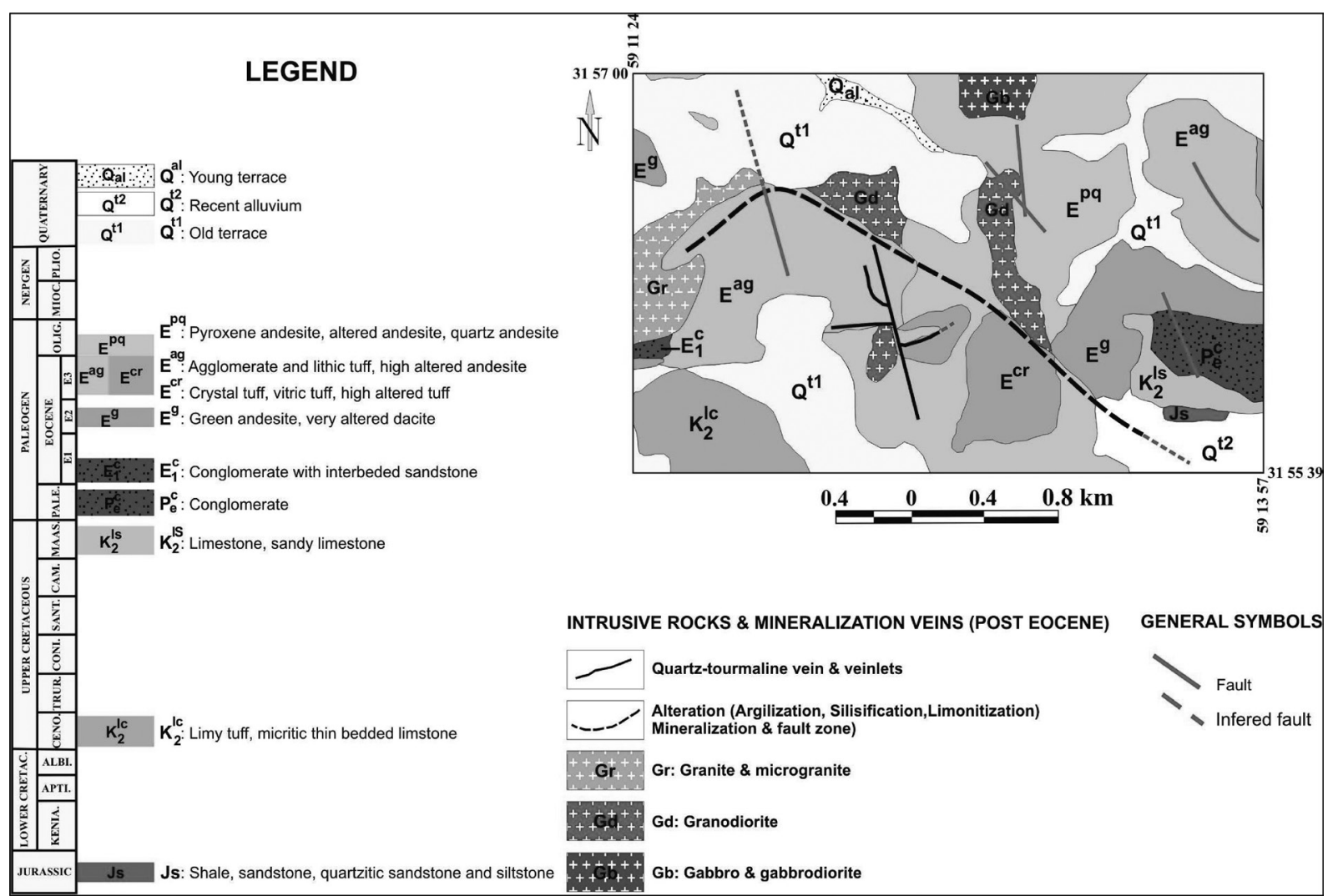

Figure 1. Geological map (scale, 1:20000) of Hired area (modified from Askari and Safari, 2004).

differ from each other in terms of the host rock, mineralogy, alteration, structure, texture and metal assemblage (Table 1) (Eshraghi et al., 2005). In the intrusion-hosted mineralization, the intrusion is the source of ore minerals, i.e., porphyry hypabyssal granodiorite-quartz diorite stock. Considering the absence of magnetite and presence of ilmenite, the intrusion is classified as an ilmenite-series or a reduced (low $f_{\mathrm{O}_{2}}$ ) intrusion. The most important minerals developed in this type of mineralization are arseno- pyrite, pyrite, pyrrhotite, sphalerite, galena, tetrahedrite, bismuthinite, chalcopyrite, and bornite, which occurred as disseminated veins and veinlets and massive textures. Associated alterations include tourmalinization, silicification, sericitization, and carbonatization. The three types of main veins and veinlets observed in intrusion-hosted mineralization are tourmaline-quartz-sulfide (TQS), quartzcalcite-sulfide (QCS), and quartz-calcite (QC); additionally, sulfide-associated veins and veinlets are observed in

Table 1. Characterizations of three-part mineralization

\begin{tabular}{|c|c|c|c|}
\hline Deposit style & Intrusion-Hosted & Proximal & Distal \\
\hline $\begin{array}{c}\text { Metal } \\
\text { Assemblage }\end{array}$ & $\begin{array}{c}\mathrm{Au}, \mathrm{As}, \mathrm{Zn}, \mathrm{Pb}, \mathrm{Cu}, \mathrm{Ag}, \mathrm{Sb}, \mathrm{Bi} \\
\text { W, Sn, Mo }\end{array}$ & $\begin{array}{l}\mathrm{Au}, \mathrm{As}, \mathrm{Zn}, \mathrm{Pb}, \mathrm{Cu}, \mathrm{Ag}, \mathrm{Sb} \\
\text { (W, Sn, Mo, Bi) }\end{array}$ & $\mathrm{Au}, \mathrm{As}, \mathrm{Ag}, \underset{\text { (W) }}{\mathrm{Sb}, \mathrm{Zn}, \mathrm{Pb}, \mathrm{Cu} \text {, }}$ \\
\hline Alteration & $\begin{array}{c}\text { Sericitic, Carbonate } \\
\text { Tourmaline, Silicic, Biotite }\end{array}$ & $\begin{array}{l}\text { Silicic, Carbonate } \\
\text { Sericitic,Tourmaline }\end{array}$ & $\begin{array}{l}\text { Silicic, Carbonate } \\
\text { Sericitic, Chlorite } \\
\text { Fe-oxides }\end{array}$ \\
\hline Mineralogy & $\begin{array}{c}\text { Arsenopyrite, Pyrite, Sphalerite, } \\
\text { Galena, Chalcopyrite, } \\
\text { Pyrrhotite, Stanite, Bornite, } \\
\text { Tetrahedrite }\end{array}$ & $\begin{array}{c}\text { Pyrite, Pyrrhotite, Sphalerite, } \\
\text { Galena, Chalcopyrite, Arsenopyrite }\end{array}$ & $\begin{array}{l}\text { Hematite, Goethite, } \\
\text { Mn-Oxides }\end{array}$ \\
\hline Host rock & Granodiorite-Quartzdiorite & Volcano-sedimentary rocks & Volcano-sedimentary rocks \\
\hline Texture \& structure & $\begin{array}{c}\text { Sheeted \& stockwork vien- } \\
\text { veinlet, Breccia, Disseminate, } \\
\text { Massive }\end{array}$ & $\begin{array}{l}\text { Sheeted \& stockwork vien-veinlet, } \\
\text { Breccia, Disseminate }\end{array}$ & Vein, Breccia \\
\hline
\end{tabular}


rare cases. Veins and veinlets are commonly observed as sheeted and stockwork systems. Mineralization corresponds to the area of dense sheeted and stockwork QCS veins and veinlets (max. $3.53 \mathrm{ppm} \mathrm{Au}$ in borehole 6) and massive sulfides (1.53 ppm Au in borehole 6).

Proximal mineralization occurred in the Eocene volcano-sedimentary sequences adjacent to the porphyry hypabyssal granodiorite-quartz diorite stock. As compared to the case of intrusion-hosted mineralization, sulfides are not abundant in this type of mineralization. The most important minerals developed in this type of mineralization are pyrite, arsenopyrite, pyrrhotite and, to a lesser extent galena and sphalerite. Sulfide minerals mainly occurred as disseminated veins and veinlets and even as massive textures. Veins and veinlets are commonly observed as stockwork systems comprising quartz, calcite, and sulfide. The dominant alterations associated with orebearing zones include sericitization, silicification and carbonatization. Hydrothermal breccia developed as a matrix supported with semi-rounded grains. The maximum gold concentration are occurred with the hydrothermal breccia.

Distal mineralization occurred in low-angle fault zones trending NE-SW and NW-SE. The fault zones can be recognized in the field as silicified and carbonate zones associated with iron oxides and hydroxides. The high gold concentration in this part is closely related to the hydrother and carbonatization associated with iron oxides and hydroxides.

A comparison of the Hired gold mineralization (i.e., tectonic setting, host rock, mineralogy, mineral paragenesis, ore content, structure and texture, and alteration) with various gold mineralization models throughout the world indicates that the mineralization is similar to gold mineralization related to the reduced granitoid intrusions described by Thompson and Newberry (2000) (Eshraghi et al., 2005; Eshraghi, 2006).

\section{MINERALOGY, SAMPLING AND ANALYTICAL METHODS}

In the Hired gold mineralization, the dominant sulfide minerals include arsenopyrite, pyrite, pyrrhotite, chalcopyrite, galena, sphalerite, bornite, stannite, stibnite, marcasite and covelite, along with minor tetrahedrite as a sulfosalt. Gold is not observed as native visible particles in the obtained samples (under a microscope); however, a chemical analysis and study of the mineralogy, alteration, structure and texture indicate that a high gold concentration is intimately related to the development of sulfides such as arsenopyrite, pyrrhotite, pyrite, galena, sphalerite and chalcopyrite. Therefore, it appears that gold has been formed as invisible or submicrometer-size inclusions in sulfide minerals. Electron probe microanalysis (EPMA) data support this assumption. Three samples having high sulfide and gold concentrations were selected for the EPMA of sulfides such as arsenopyrite, pyrite, pyrrhotite, galena, sphalerite, and stannite (Table 2). EPMA of the aforementioned minerals were carried out using Cameca SX100 at the Iranian Mineral Processing Research Center. The signals and standards used for the elements are listed in Table 3. A beam current of $20 \mathrm{nA}$ at an accelerating voltage of $20 \mathrm{kV}$ with a beam size of $3 \mu \mathrm{m}$ was used. The counting time was $20 \mathrm{~s}$, the standard used was pure $\mathrm{Au}$ metal $(99.99 \%)$, and the detection limit for gold was 100 ppm.

\section{GENESIS AND PARAGENETIC SEQUENCES OF MINERALS}

Based on field observations, hand specimens, polished thin sections, and EPMA, three stages of mineralization are recognized in the Hired gold mineralization. The first stage occurred as a hypabyssal porphyry granodioritequartz diorite intrusion emplaced in Eocene volcano-sedimentary units, resulting in skarn and calcsilicate hornfelses. A propylitic alteration of different intensity coincides with the aforementioned intrusion. In the next stage, the system passes from the magmatic to the hydrothermal stage, which is divided into the early and late processes. In the early hydrothermal stage tourmalinization, silicification and some sericitization occurred along with sulfides such as arsenopyrite, pyrite and pyrrhotite as disseminated veins and veinlets as well as massive textures of TQS. The late hydrothermal stage is associated with sericitization, carbonatization, and silicification and the development of sulfides such as arsenopyrite, pyrite, pyrrhotite, galena, sphalerite, stannite, chalcopyrite, tetrahedrite, bornite and stibnite. Because native gold has not been observed in various sulfides of the early and late hydrothermal stages, it can be concluded that gold entrapment in sulfides is coincident with their formation, beginning from the early hydrothermal stage and lasting up to the late hydrothermal stage. Due to the correlation of high gold concentration with sericitization and carbonatization, it can be hypothesized that the maximum gold concentration and deposition occurred in the late hydrothermal stage. The textures developed in the hydrothermal stage are disseminated, massive, veins and veinlets and brecciated mineralization.

At the supergene weathering stage, the oxidation of primary sulfides occurred and almost no traces of sulfides can be observed in the samples. Supergene weathering occurred only up to a small depth in the Hired gold mineralization; however, due to the development of faults and 
Table 2. Samples having high sulfide and gold concentrations selected for EPMA

\begin{tabular}{|c|c|c|c|c|c|c|}
\hline Minerals & $\begin{array}{l}\text { No. Sample, } \\
\text { Interval }\end{array}$ & Mineralization & Paragenesis & $\begin{array}{l}\text { Texture and } \\
\text { size }\end{array}$ & $\begin{array}{l}\text { Figure } \\
\text { and } \\
\text { analysis } \\
\text { table }\end{array}$ & Comment \\
\hline Arsenopyrite & $\begin{array}{c}\text { B44, borehole } 6, \\
82 \text { to } 92 \mathrm{~m} \text {. }\end{array}$ & Intrusion-hosted & $\begin{array}{c}\text { Sphalerite, } \\
\text { Galena, } \\
\text { Stannite, } \\
\text { Chalcopyrite, } \\
\text { Pyrrhotite, } \\
\text { Pyrite }\end{array}$ & $\begin{array}{l}\text { Euhedral, } 20 \\
\mu \mathrm{m}-0.5 \mathrm{~mm} .\end{array}$ & $\begin{array}{l}\text { Fig.2, } \\
\text { Table } 4\end{array}$ & $\begin{array}{l}\text { Most abundant sulfide } \\
\text { exist in high gold } \\
\text { concentration }\end{array}$ \\
\hline Arsenopyrite & $\begin{array}{c}\text { B47, borehole } 7 \\
2 \text { to } 17 \mathrm{~m} .\end{array}$ & Proximal & Pyrite & $\begin{array}{l}\text { Euhedral, } \\
\text { disseminated }\end{array}$ & $\begin{array}{l}\text { Fig.3, } \\
\text { Table } 5\end{array}$ & $\begin{array}{l}\text { Quartz and calcite } \\
\text { veins and veinlets, } \\
\text { Inclusions in pyrite }\end{array}$ \\
\hline Pyrite & $\begin{array}{l}\text { B38, borehole } 6 \text {, } \\
59 \text { to } 65 \mathrm{~m} .\end{array}$ & Intrusion-hosted & $\begin{array}{c}\text { Arsenopyrite, } \\
\text { Pyrrhotite }\end{array}$ & $\begin{array}{l}\text { Euhedral to } \\
\text { anhedral, } \\
\text { disseminated, } \\
100-700 \mu \mathrm{m}\end{array}$ & $\begin{array}{l}\text { Fig. } 2, \\
\text { Table } 6\end{array}$ & $\begin{array}{l}\text { Most abundant sulfide } \\
\text { next to the } \\
\text { arsenopyrite, } \\
\text { Inclusions in pyrrhotite }\end{array}$ \\
\hline Pyrite & $\begin{array}{c}\text { B47, borehole } 7 \\
2 \text { to } 17 \mathrm{~m} .\end{array}$ & Proximal & Arsenopyrite & $\begin{array}{c}\text { Euhedral to } \\
\text { subhedral }\end{array}$ & $\begin{array}{l}\text { Fig.3, } \\
\text { Table } 7\end{array}$ & $\begin{array}{c}\text { Accompanying } \\
\text { arsenopyrite in quartz } \\
\text { and calcite veins and } \\
\text { veinlets }\end{array}$ \\
\hline Pyrrhotite & $\begin{array}{l}\text { B38, borehole } 6 \text {, } \\
59 \text { to } 65 \mathrm{~m} \text {. }\end{array}$ & Intrusion-hosted & $\begin{array}{c}\text { Arsenopyrite, } \\
\text { Chalcopyrite, } \\
\text { Pyrite }\end{array}$ & $\begin{array}{c}\text { Disseminated } \\
\text { and anhedral } \\
\text { phenocryst, } \\
3 \mathrm{~mm} .\end{array}$ & $\begin{array}{l}\text { Fig.2, } \\
\text { Table } 8\end{array}$ & Third abundant \\
\hline Sphalerite & $\begin{array}{l}\text { B44, borehole6, } \\
82 \text { to } 92 \mathrm{~m} \text {. }\end{array}$ & Intrusion-hosted & $\begin{array}{c}\text { Chalcopyrite, } \\
\text { Stannite }\end{array}$ & $\begin{array}{l}\text { Anhedral, 100- } \\
\quad 700 \mu \mathrm{m}\end{array}$ & Fig.4 & $\begin{array}{l}\text { Overgrew chalcopyrite } \\
\text { and stannite, Due to } \\
\text { sphalerite have } \\
\text { elements that } \\
\text { laboratory hasn't } \\
\text { necessary standards, } \\
\text { therefore the total } \\
\text { percentage of elements } \\
\text { did not amount to } \\
\text { required level and the } \\
\text { data is not reliable }\end{array}$ \\
\hline Galena & $\begin{array}{l}\text { B44, borehole } 6 \text {, } \\
82 \text { to } 92 \mathrm{~m} .\end{array}$ & Intrusion-hosted & $\begin{array}{l}\text { Sphalerite, } \\
\text { Galena, } \\
\text { Stannite, }\end{array}$ & $\begin{array}{l}\text { Anhedral } \\
\text { twinned, } \\
\text { disseminated } \\
\text { and veinlets, } \\
10-100 \mu \mathrm{m} .\end{array}$ & $\begin{array}{l}\text { Fig. } 4 \text {, } \\
\text { Table } 9\end{array}$ & $\begin{array}{l}\text { Developed between } \\
\text { quartz crystals, in } \\
\text { highly silicified parts }\end{array}$ \\
\hline Chalcopyrite & $\begin{array}{l}\text { B44, borehole } 6 \text {, } \\
\text { from } 82 \text { to } 92 \mathrm{~m} \text {. }\end{array}$ & Intrusion-hosted & $\begin{array}{l}\text { Sphalerite, } \\
\text { Stannite, } \\
\text { Galena, } \\
\text { Pyrrhotite }\end{array}$ & $\begin{array}{l}\text { Anhedral } \\
\text { disseminated } \\
\text { mineral, 30- } \\
400 \mu \mathrm{m} \text {. }\end{array}$ & Table 10 & $\begin{array}{l}\text { Overgrowth with } \\
\text { sphalerite and stannite } \\
\text { as exsolusion texture }\end{array}$ \\
\hline Stannite & $\begin{array}{l}\text { B 44, borehole } 6 \text {, } \\
\text { from } 82 \text { to } 92 \mathrm{~m} \text {. }\end{array}$ & Intrusion-hosted & $\begin{array}{l}\text { Sphalerite, } \\
\text { Chalcopyrite }\end{array}$ & Anhedral & $\begin{array}{l}\text { Fig.4, } \\
\text { Table } 11\end{array}$ & $\begin{array}{c}\text { Only Sn-bearing } \\
\text { mineral, exsolusion as } \\
\text { emulsions, framework } \\
\text { and graphic }\end{array}$ \\
\hline
\end{tabular}

shear zones, the depth varies. Supergene weathering was accompanied with the development of a variety of secondary minerals such as quartz, calcite, kaolinite, covelite, goethite, lepidocrocite and hematite. Supergene weathering led to an increased gold concentration near the surface. The samples obtained from trenches, exhibited a greater gold concentration than core samples. Figure 5 il- lustrates the processes involved in the formation of the Hired gold mineralization.

\section{DISCUSSION}

The main objective of the present study is the recognition of Au-bearing sulfides. The maximum gold concentra- 
Table 3. Signals and standards used for elements in EPMA

\begin{tabular}{ccc}
\hline Elements & Signal $(\mathrm{s})$ & Standard composition \\
\hline $\mathrm{S}$ & $\mathrm{Ka}$ & Chalcopyrite $=\mathrm{Cu}: 34.63 \%, \mathrm{Fe}: 30.43 \%, \mathrm{~S}: 34.94 \%$ \\
$\mathrm{Fe}$ & $\mathrm{Ka}$ & Chalcopyrite $=\mathrm{Cu}: 34.63 \%, \mathrm{Fe}: 30.43 \%, \mathrm{~S}: 34.94 \%$ \\
$\mathrm{Cu}$ & $\mathrm{Ka}$ & Chalcopyrite $=\mathrm{Cu}: 34.63 \%, \mathrm{Fe}: 30.43 \%, \mathrm{~S}: 34.94 \%$ \\
$\mathrm{Zn}$ & $\mathrm{Ka}$ & Sphalerite $=\mathrm{Zn}: 67.1 \%, \mathrm{~S}: 32.90 \%$ \\
$\mathrm{Ag}$ & $\mathrm{La}$ & Hessite $=\mathrm{Ag}: 62.84 \%, \mathrm{Te}: 37.16 \%$ \\
$\mathrm{Te}$ & $\mathrm{La}$ & $\mathrm{Hessite}=\mathrm{Ag}: 62.84 \%, \mathrm{Te}: 37.16 \%$ \\
$\mathrm{Sn}$ & $\mathrm{La}$ & $\mathrm{Sn}: 100 . \%$ \\
$\mathrm{Sb}$ & $\mathrm{La}$ & $\mathrm{Au}: 99.99 \%$ \\
$\mathrm{Au}$ & $\mathrm{La}$ & Indium Antimonide $=\mathrm{In}: 48.53 \%, \mathrm{Sb}: 51.46 \%$ \\
$\mathrm{~Pb}$ & $\mathrm{Ma}$ & $\mathrm{Bi}=\mathrm{Bi}: 100 \%$ \\
$\mathrm{Bi}$ & $\mathrm{La}$ & $\mathrm{Galena}=\mathrm{Pb}: 86.60 \%, \mathrm{~S}: 13.40 \%$ \\
$\mathrm{As}$ & $\mathrm{La}$ & $\mathrm{GaAs}=\mathrm{Ga}: 48.21 \%, \mathrm{As:} 51.79 \%$ \\
\hline
\end{tabular}

Table 4. Representative EPMA of arsenopyrite from intrusion-hosted mineralization

\begin{tabular}{ccccccccccc}
\hline Point & $\mathrm{S}$ & $\mathrm{Fe}$ & $\mathrm{As}$ & $\mathrm{Au}$ & $\mathrm{Cu}$ & $\mathrm{Ag}$ & $\mathrm{Sb}$ & $\mathrm{Te}$ & $\mathrm{Bi}$ & $\mathrm{Total}$ \\
\hline 1.00 & 19.29 & 35.63 & 45.20 & 0.05 & 0.00 & 0.00 & 0.03 & 0.00 & 0.00 & 100.19 \\
2.00 & 19.56 & 35.64 & 44.91 & 0.00 & 0.00 & 0.04 & 0.03 & 0.13 & 0.00 & 100.30 \\
3.00 & 19.39 & 35.69 & 45.27 & 0.00 & 0.00 & 0.07 & 0.10 & 0.03 & 0.00 & 100.53 \\
4.00 & 19.32 & 35.65 & 45.37 & 0.00 & 0.01 & 0.05 & 0.01 & 0.12 & 0.00 & 100.52 \\
5.00 & 19.04 & 35.69 & 45.77 & 0.02 & 0.00 & 0.08 & 0.02 & 0.02 & 0.00 & 100.64 \\
6.00 & 21.23 & 36.17 & 41.98 & 0.00 & 0.00 & 0.00 & 1.03 & 0.00 & 0.00 & 100.41 \\
7.00 & 20.92 & 36.28 & 43.44 & 0.07 & 0.02 & 0.00 & 0.10 & 0.00 & 0.06 & 100.89 \\
8.00 & 20.91 & 35.98 & 42.69 & 0.00 & 0.02 & 0.00 & 0.55 & 0.00 & 0.00 & 100.19 \\
9.00 & 20.49 & 35.70 & 41.93 & 0.00 & 0.00 & 0.00 & 1.32 & 0.07 & 0.00 & 99.49 \\
10.00 & 20.66 & 36.49 & 43.23 & 0.04 & 0.00 & 0.00 & 0.07 & 0.03 & 0.00 & 100.52 \\
11.00 & 20.30 & 35.61 & 43.08 & 0.01 & 0.00 & 0.00 & 0.17 & 0.04 & 0.00 & 99.20 \\
\hline
\end{tabular}

All elements given in $w t \%$.

Table 5. Representative EPMA of arsenopyrite from proximal mineralization

\begin{tabular}{cccccccccccc}
\hline Point & $\mathrm{S}$ & $\mathrm{Fe}$ & $\mathrm{As}$ & $\mathrm{Au}$ & $\mathrm{Cu}$ & $\mathrm{Ag}$ & $\mathrm{Sb}$ & $\mathrm{Te}$ & $\mathrm{Bi}$ & $\mathrm{Total}$ \\
\hline 1.00 & 21.07 & 35.82 & 43.91 & 0.00 & 0.00 & 0.00 & 0.05 & 0.00 & 0.00 & 100.85 \\
2.00 & 21.74 & 35.97 & 42.68 & 0.01 & 0.00 & 0.00 & 0.00 & 0.00 & 0.00 & 100.41 \\
3.00 & 21.06 & 36.00 & 42.56 & 0.00 & 0.02 & 0.00 & 0.00 & 0.03 & 0.00 & 99.67 \\
4.00 & 20.42 & 35.68 & 43.71 & 0.00 & 0.01 & 0.01 & 0.00 & 0.00 & 0.00 & 99.83 \\
5.00 & 23.35 & 35.59 & 41.05 & 0.04 & 0.00 & 0.06 & 0.10 & 0.00 & 0.00 & 100.18 \\
\hline
\end{tabular}

All elements given in wt $\%$.

tions were measured in various minerals such as pyrrhotite (4470 ppm), galena (790 ppm), pyrite (1930 ppm) and arsenopyrite $(740 \mathrm{ppm})$; however, due to the relative abundance of arsenopyrite and pyrite as compared to galena and pyrrhotite in the sulfidized parts, the main parameter determining the gold concentration is the development of the two former minerals. However, the present study confirmed invisible gold entrapment in the aforementioned sulfide minerals (Tables 4-11 and Figs. 2-4).

There are several arguments on the occurrence of invisible gold in sulfides. Gold attachment to the sulfides depends on the (1) stoichiometry, (2) stability of Au-bearing complexes and (3) suitability of chemical bonds (Andreas et al., 2003). Saha and Venkatesh (2002) believed that gold $\left(\mathrm{Au}^{+3}\right)$ replaced iron $\left(\mathrm{Fe}^{+3}\right)$ in the sulfide structure. Boyle (1979) and Cook and Chryssoulis (1990) believed that $\mathrm{Au}$ replaced As in arsenopyrite because of the similar ionic radius and covalent bonds. Johan et al. (1989) carried out EPMA of $\mathrm{Au}$-bearing arsenopyrite and performed stoichiometric calculations, and they concluded that Au replaces excess As at the Fe position. Fleet et al. (1993) and Knipe et al. (1992) believed that adsorp- 
Table 6. Representative EPMA of pyrite from intrusion-hosted mineralization

\begin{tabular}{ccccccccccc}
\hline Point & $\mathrm{S}$ & $\mathrm{Fe}$ & $\mathrm{As}$ & $\mathrm{Au}$ & $\mathrm{Cu}$ & $\mathrm{Ag}$ & $\mathrm{Sb}$ & $\mathrm{Te}$ & $\mathrm{Bi}$ & $\mathrm{Total}$ \\
\hline 1.00 & 53.71 & 46.48 & 0.06 & 0.01 & 0.00 & 0.00 & 0.00 & 0.06 & 0.00 & 100.32 \\
2.00 & 53.41 & 46.27 & 0.00 & 0.19 & 0.01 & 0.05 & 0.00 & 0.05 & 0.00 & 100.02 \\
3.00 & 53.68 & 46.87 & 0.01 & 0.00 & 0.00 & 0.00 & 0.03 & 0.05 & 0.08 & 100.71 \\
4.00 & 53.29 & 46.34 & 0.47 & 0.00 & 0.00 & 0.05 & 0.00 & 0.03 & 0.00 & 100.18 \\
5.00 & 53.43 & 46.61 & 0.13 & 0.00 & 0.00 & 0.00 & 0.02 & 0.08 & 0.01 & 100.29 \\
\hline
\end{tabular}

All elements given in $w t \%$.

Table 7. Representative EPMA of pyrite from proximal mineralization

\begin{tabular}{cccccccccccc}
\hline Point & $\mathrm{S}$ & $\mathrm{Fe}$ & $\mathrm{As}$ & $\mathrm{Au}$ & $\mathrm{Cu}$ & $\mathrm{Ag}$ & $\mathrm{Sb}$ & $\mathrm{Te}$ & $\mathrm{Bi}$ & $\mathrm{Total}$ \\
\hline 1.00 & 52.34 & 45.92 & 0.87 & 0.00 & 0.02 & 0.08 & 0.02 & 0.09 & 0.02 & 99.35 \\
2.00 & 52.75 & 46.70 & 0.72 & 0.00 & 0.03 & 0.00 & 0.00 & 0.00 & 0.30 & 100.50 \\
3.00 & 53.08 & 47.08 & 0.02 & 0.03 & 0.03 & 0.05 & 0.01 & 0.00 & 0.39 & 100.67 \\
4.00 & 51.48 & 46.72 & 1.65 & 0.00 & 0.03 & 0.00 & 0.00 & 0.00 & 0.00 & 99.87 \\
\hline
\end{tabular}

All elements given in $w t \%$.

Table 8. Representative EPMA of pyrrhotite from intrusion-hosted mineralization

\begin{tabular}{ccccccccccc}
\hline Point & $\mathrm{S}$ & $\mathrm{Fe}$ & $\mathrm{As}$ & $\mathrm{Au}$ & $\mathrm{Cu}$ & $\mathrm{Ag}$ & $\mathrm{Sb}$ & $\mathrm{Te}$ & $\mathrm{Bi}$ & $\mathrm{Total}$ \\
\hline 1.00 & 40.48 & 59.45 & 0.00 & 0.45 & 0.07 & 0.00 & 0.00 & 0.00 & 0.05 & 100.50 \\
2.00 & 39.64 & 59.71 & 0.00 & 0.00 & 0.00 & 0.01 & 0.09 & 0.01 & 0.00 & 99.46 \\
3.00 & 40.41 & 59.34 & 0.00 & 0.00 & 0.00 & 0.00 & 0.00 & 0.00 & 0.33 & 100.07 \\
4.00 & 39.77 & 59.74 & 0.09 & 0.16 & 0.00 & 0.00 & 0.00 & 0.00 & 0.10 & 99.85 \\
5.00 & 40.39 & 59.24 & 0.04 & 0.00 & 0.00 & 0.05 & 0.05 & 0.00 & 0.00 & 99.76 \\
\hline
\end{tabular}

All elements given in $\mathrm{wt} \%$.

Table 9. Representative EPMA of galena from intrusion-hosted mineralization

\begin{tabular}{ccccccccccc}
\hline Point & $\mathrm{S}$ & $\mathrm{Pb}$ & $\mathrm{Au}$ & $\mathrm{Cu}$ & $\mathrm{Zn}$ & $\mathrm{Ag}$ & $\mathrm{Sn}$ & $\mathrm{Sb}$ & $\mathrm{Fe}$ & $\mathrm{Total}$ \\
\hline 1.00 & 13.28 & 87.05 & 0.00 & 0.00 & 0.04 & 0.09 & 0.08 & 0.17 & 0.00 & 100.90 \\
2.00 & 13.33 & 85.43 & 0.18 & 0.00 & 0.01 & 0.08 & 0.03 & 0.19 & 0.01 & 99.33 \\
3.00 & 13.19 & 85.27 & 0.01 & 0.00 & 0.00 & 0.31 & 0.07 & 0.37 & 0.01 & 99.21 \\
4.00 & 13.03 & 85.94 & 0.00 & 0.00 & 0.03 & 0.17 & 0.07 & 0.17 & 0.02 & 99.42 \\
5.00 & 14.14 & 86.39 & 0.00 & 0.01 & 0.00 & 0.21 & 0.09 & 0.18 & 0.01 & 101.00 \\
\hline
\end{tabular}

All elements given in $w t \%$.

Table 10. Representative EPMA of chalcopyrite from intrusion-hosted mineralization

\begin{tabular}{cccccccccccc}
\hline Point & $\mathrm{S}$ & $\mathrm{Cu}$ & $\mathrm{Fe}$ & $\mathrm{Au}$ & $\mathrm{Ag}$ & $\mathrm{Sn}$ & $\mathrm{Sb}$ & $\mathrm{Te}$ & $\mathrm{Bi}$ & Total \\
\hline 1.00 & 34.43 & 34.39 & 29.95 & 0.00 & 0.05 & 0.43 & 0.00 & 0.04 & 0.00 & 99.28 \\
2.00 & 34.07 & 34.48 & 30.11 & 0.00 & 0.12 & 0.24 & 0.00 & 0.03 & 0.00 & 99.04 \\
3.00 & 34.04 & 34.44 & 30.05 & 0.00 & 0.15 & 0.19 & 0.00 & 0.00 & 0.08 & 98.96 \\
4.00 & 35.13 & 33.49 & 30.86 & 0.00 & 0.08 & 0.24 & 0.01 & 0.04 & 0.00 & 99.85 \\
\hline
\end{tabular}

All elements given in $\mathrm{wt} \%$.

Table 11. Representative EPMA of stannite from intrusion-hosted mineralization

\begin{tabular}{cccccccccccc}
\hline Point & $\mathrm{S}$ & $\mathrm{Cu}$ & $\mathrm{Zn}$ & $\mathrm{Sn}$ & $\mathrm{Au}$ & $\mathrm{Ag}$ & $\mathrm{Te}$ & $\mathrm{Pb}$ & $\mathrm{Bi}$ & $\mathrm{Fe}$ \\
\hline 1.00 & 28.79 & 28.92 & 1.04 & 27.38 & 0.00 & 0.18 & 0.00 & 0.00 & 0.10 & 12.69 & 99.09 \\
2.00 & 27.97 & 28.75 & 2.68 & 27.29 & 0.00 & 0.20 & 0.00 & 0.00 & 0.01 & 12.40 & 99.28 \\
3.00 & 28.81 & 28.93 & 2.07 & 27.61 & 0.00 & 0.21 & 0.00 & 0.00 & 0.05 & 12.48 & 100.15 \\
4.00 & 29.77 & 29.07 & 1.89 & 26.62 & 0.00 & 0.08 & 0.00 & 0.00 & 0.00 & 12.73 & 100.17 \\
5.00 & 29.64 & 28.24 & 2.30 & 27.03 & 0.00 & 0.24 & 0.00 & 0.00 & 0.04 & 12.66 & 100.16 \\
\hline
\end{tabular}

All elements given in wt $\%$. 


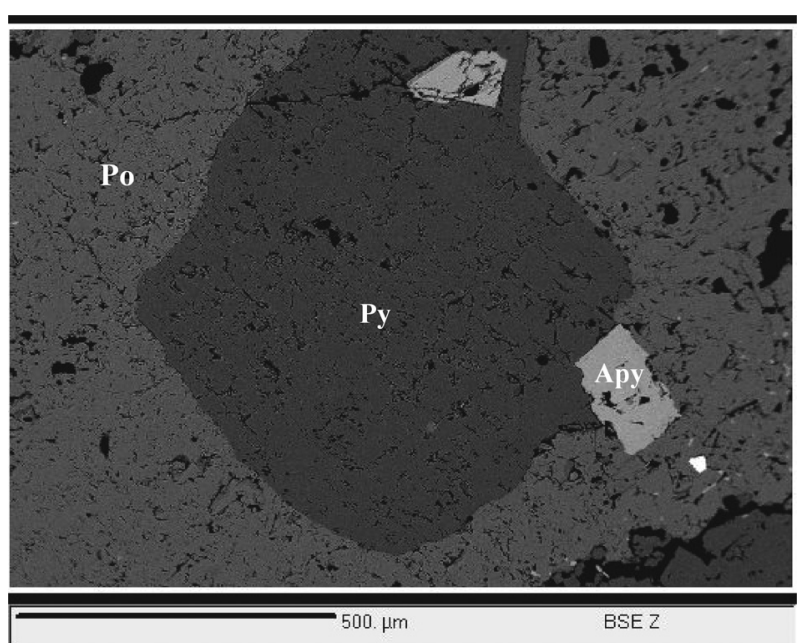

Figure 2. BSE image of arsenopyrite (Apy), pyrite (Py) and pyrrhotite $(\mathrm{Po})$

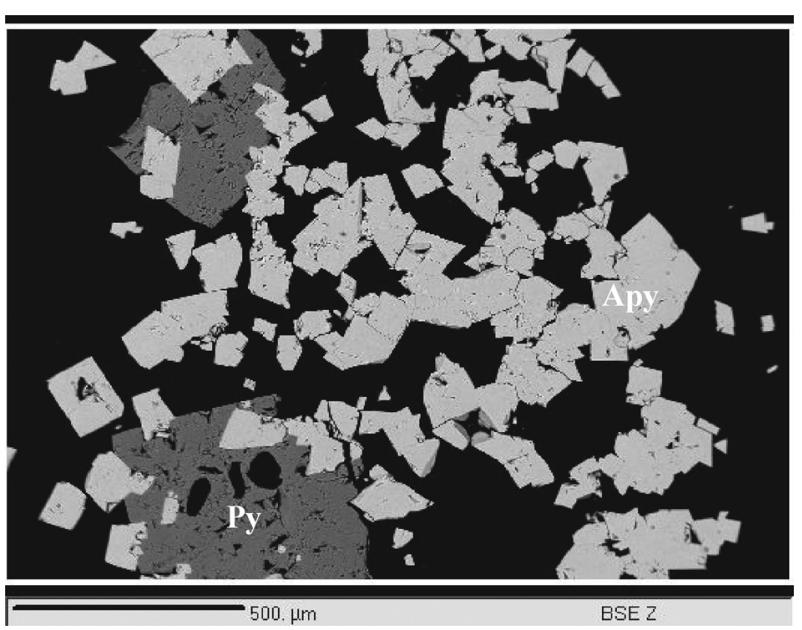

Figure 3. BSE image of arsenopyrite (Apy) and pyrite (Py).

tion-redox reactions on sulfide growth surfaces are important during $\mathrm{Au}$-bearing sulfide formation. $\mathrm{Au}^{+}$adsorbed on pyrite growing surfaces from fluids containing hydrosulfide complexes during which $\mathrm{Au}^{\circ}$ formed because of the reduction of $\mathrm{Au}^{+}$from $\mathrm{Au}-\mathrm{HS}$ fluids (Scaini, 1998; Scaini et al., 1997). Andras et al. (2003) reported that Au could deposit at deflections and void spaces on the mineral surfaces.

Previous studies have suggested that Au can exist in sulfide minerals in the ionic and native forms and in the form of inclusions of Au-bearing minerals. All the possible cases discussed above may result in the invisible gold in the Hired gold mineralization. X-ray photoelectron spectroscopy (XPS), field-emission scanning electron microscopy (FE-SEM) and secondary ion mass spectroscopy (SIMS) analysis have provided a better understanding of how gold emplaces sulfides (Maddox et al., 1998; Mcmahan and Cabri, 1998; Cabri et al., 1991)

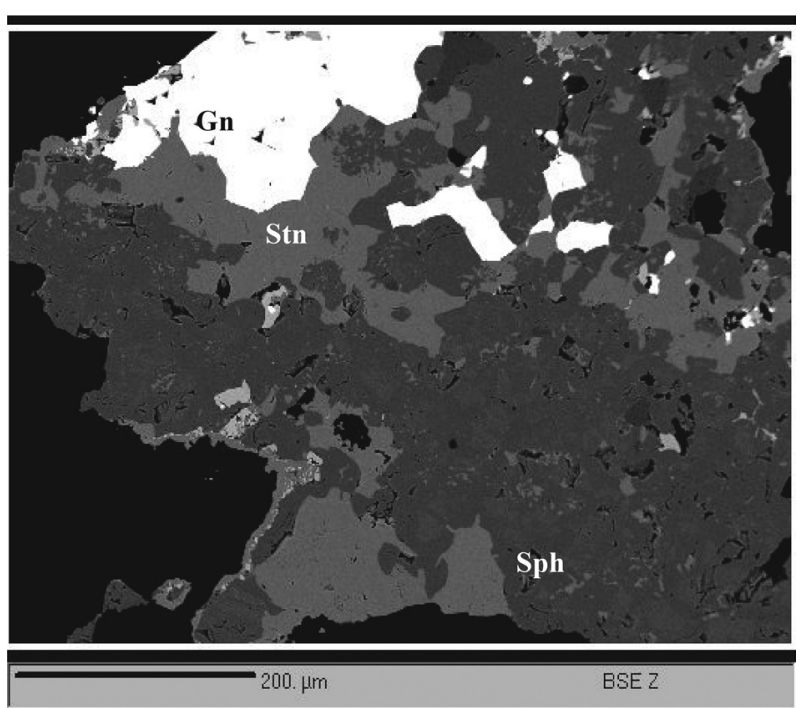

Figure 4. BSE image of sphalerite (Sph), galena (Gn), and stannite (Stn).

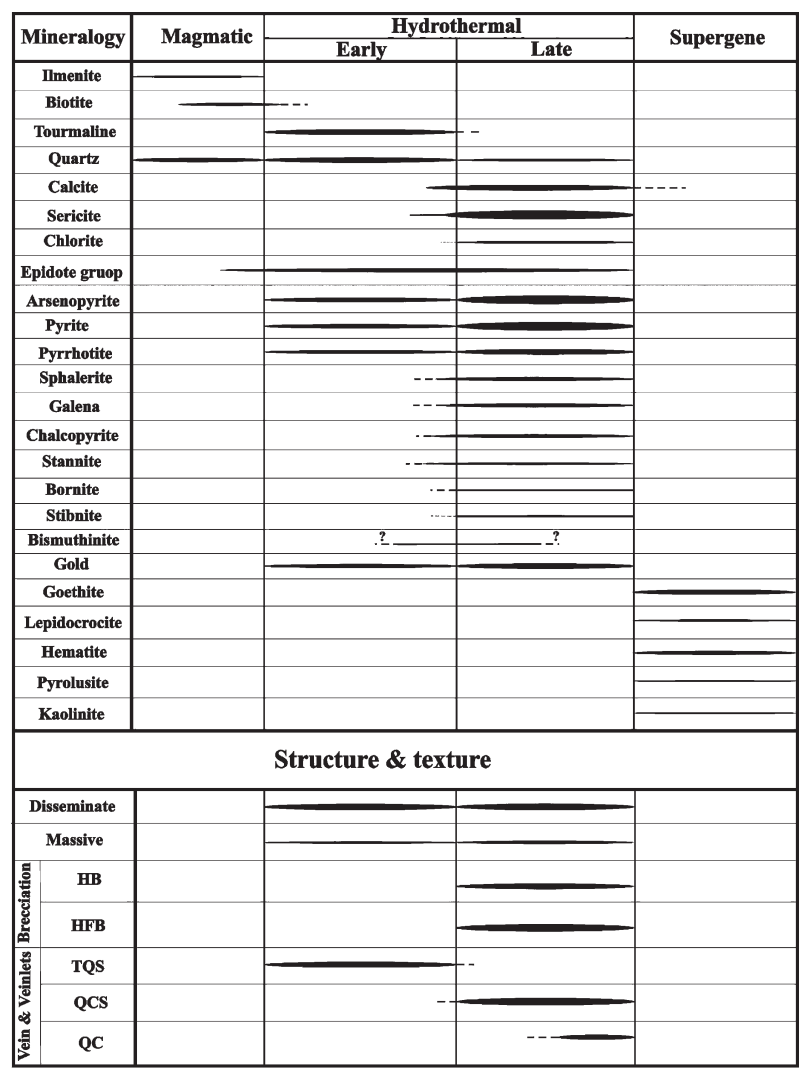

Figure 5. Paragenetic sequences of Hired gold mineralization. Abbreviations: HB, hydrothermal breccias; FHB, hydrothermal fault breccias; QC, quartz-calcite vein/veinlet; QCS, quartz-calcitesulfide vein/veinlet; TQS, tourmaline-quartz-sulfide vein/veinlet.

With regard to paragenetic sequences, gold deposition as invisible particles occurred throughout various stages of mineralization. In other words, at high temperatures coinciding with silicification-tourmalinization, gold 
occurred in arsenopyrite, pyrite and pyrrhotite, whereas at medium and low temperatures coinciding with sericitization, carbonatization and silicification, gold occurred in arsenopyrite, pyrite, pyrrhotite and galena (Fig. 5).

As mentioned before, the high gold concentration in some sulfides is due to submicrometer-size inclusions of $\mathrm{Au}$-bearing minerals in their structure. With regard to the presence of $\mathrm{Ag}, \mathrm{Te}$ and $\mathrm{Sb}$ as well as $\mathrm{Au}$ in arsenopyrite and pyrite structures, the suggestion that gold probably exists in arsenopyrite and pyrite structures as submicrometer-size inclusions of electrum, calaverite $\left(\mathrm{AuTe}_{2}\right)$, silvanite $\left(\mathrm{Ag}, \mathrm{AuTe}_{4}\right)$, kernnerite $\left(\mathrm{Au}, \mathrm{AgTe}_{2}\right)$ and aurostibite (AuSb2) requires further analysis. Moreover, galena contains considerable amounts of $\mathrm{Ag}, \mathrm{Au}$ and $\mathrm{Te}$, which may indicate submicrometer-size minerals such as hessite $\left(\mathrm{Ag}_{2} \mathrm{Te}\right)$, electrum and petzite $\left(\mathrm{Ag}_{3} \mathrm{AuTe}_{2}\right)$ or invisible particles of metallic gold or chemically bound gold.

The EPMA and mineralographic study of the obtained samples did not indicate the presence of any particular mineral of Ag. The anomalous detection of $\mathrm{Ag}$ is due to its existence in galena, stannite, chalcopyrite, arsenopyrite, pyrite and to a lesser extent, pyrrhotite.

\section{ACKNOWLEDGMENTS}

We greatly appreciate the assistance provided by the authorities and staff of the Tarbiat Modarres University (TMU), Pars Oil and Gas Company (POGC) and the Geological Survey of Iran (GSI) throughout this research. The authors are also grateful to Dr. Mehrabi for his thorough review of our manuscript.

\section{SUPPLEMENTARY MATERIAL}

Color version of Figures 1 is available online from http:// www.jstage.jst.go.jp/browse/jmps.

\section{REFERENCES}

Andras, P., Chovan, M.M. and Ozdin, D. (2003) Incorporation of "Invisible Gold" to the sulfides minerals from Tatric Unite (Western Carpathians, Slovak Republic). Acta Mineralogica, Abstract Series 1, Szeget.

Askari, A. and Safari., M. (2004) Report of geological map (1:20000) from Hired gold mineralization district, Geological survey of Iran (GSI).

Boyle, R.W. (1979) the geochemistry of gold and its deposits (together with a chapter on geochemical prospecting for the element). pp. 584, Energy, Mines, and Resources Canada, Geological Survey of Canada 280.

Cabri, L.J., Chryssoulis, S.L., Campbell, J.L. and Teesdale, W.J. (1991) Comparison of in-situ gold analyses in arsenian pyrite. Applied Geochemistry, 6, 225-230.

Camp, V.E. and Griffis, R.J. (1982) Character, genesis and tectonic setting of igneous rock in the Sistan Suture Zone eastern Iran. Lithos, ISSN 0024-4978, NOR., DA. 1982.

Cook, N.J. and Chryssoulis, S.L. (1990) Concentration of invisible gold in common sulfides. Canadian Mineralogist, 28, 1-16.

Eshraghi, H. (2006) Mineralogy, geochemistry and type of gold mineralization in Hired district. pp. 215, MS. Thesis, Tarbiat Modarres University, Tehran, Iran.

Eshraghi, H., Rastad, E., Emami, M.H. and Askari, A. (2005) The Hired gold mineralization: an example of gold deposits related to reduced granitoid intrusions. The $24^{\text {th }}$ Symposium on Geosciences, Geological survey of Iran (GSI).

Fleet, M.E., Chryssoulis, S.L., MacLean, P.J., Davidson, R. and Weisener, G. (1993) Arsenian pyrite from gold deposits: Au and As distribution investigation by SIMS and RP, and color staining and surface oxidation by XPS and LIMS. Canadian Mineralogist, 31, 1-17.

Ishihara, S. (1981) The granitoid series and mineralization. Economic Geology, $75^{\text {th }}$ Anniversary, 458-484.

Johan, Z., Marcoux, E. and Bonnemaison, M. (1989) Arsenopyrite Aurifere: Mode de Substitution de Au dans la Structure de Fe As S. Comptes Rendus de l'Académie des sciences, 308 (II), 185-191.

Knipe, S.W., Foster, R.P. and Stanley, C.J. (1992) Role of sulphide surfaces in sorption of precious metals from hydrothermal fluids. Institute of Mining and Metallurgy, Transactions, Section B: Applied Earth Science, 101, B83-B88.

Maddox, L.M., Bancroft, G.M., Scaini, M.J. and Lorimer, J.W. (1998) Invisible gold: Comparison of Au deposition on pyrite and arsenopyrite. American Mineralogist, 83, 1240-1245.

McMahon, G., and Cabri, L.J. (1998) The SIMS technique on ore mineralogy. Mineralogical Association of Canada, Short Course Series, 27, 199-240.

Saha, I. and Venkatesh, A.S. (2002) Geological and structural India. Abstract of $31^{\text {st }}$ IGC, Brazil 2002.

Scaini, M.J. (1998) Reactions of aqueous Au11 sulfide species with pyrite as a function of $\mathrm{pH}$ and temperature. American Mineralogist, 83, 316-322.

Scaini, M.J., Bancroft, G.M. and Knipe, S.W. (1997) An XPS, AES and SEM Study of the interactions of gild and silver chloride species with $\mathrm{PbS}$ and $\mathrm{FeS}_{2}$ : Comparison to natural samples. Geochemica et Cosmochemica Acta, 61, 1223-1231.

Sengor, A.M.C. (1990) A new model for the late Paleozoic-Mesozoic tectonic evolution of Iran and implications for Oman. In the Geology and Tectonics of the Oman Region (Robertson, A.H.F., Searle, M.P. and Ries, A.C. Eds.). Geological Society of London Special Publication, 49, 797-831.

Sillitoe, R.H. (2005) Comments on the Chah shalghami, Hired, Maherabad, Khonick and Shurab gold prospects, Lut Block, Eastern Iran. Geological survey of Iran (GSI).

Thompson, J.F.H. and Newberry, R.J. (2000) Gold deposits Related to Reduced granitic intrusion. Society of Economic Geology Reviews, 13, 377-400.

Tirrul, R., Bell, I.R., Griffis, R.J. and Camp, V.E. (1983) The Sis$\tan$ suture zone of eastern Iran. The Geological Soceity of America Bulletin, 194, 134-150.

\author{
Manuscript received April 14, 2007 \\ Manuscript accepted October 14, 2009 \\ Published online June 15, 2010 \\ Manuscript handled by Hiroaki Matsueda
}

